\title{
Inherited Color Blindness
}

National Cancer Institute

\section{Source}

National Cancer Institute. Inherited Color Blindness. NCI Thesaurus. Code C118713.

Genetic based difficulty in distinguishing colors. 